\title{
The Effect of Learning-Based Learning Approach to Local Invitation and the Value of Interest in the Development of Characters of Elementary School Students
}

\author{
Fifit Sahputra ${ }^{1}$, Yusrizal ${ }^{2}$, Fatmawati ${ }^{3}$ \\ \{fitsahputra@gmail.com¹, yusrizalr2@gmail.com², fatmecincau22@gmail.com ${ }^{3}$ \} \\ ${ }^{1}$ Postgraduate Program Students, Universitas Negeri Medan Indonesia, Indonesia \\ ${ }^{2,3}$ STKIP Amal Bakti, Medan Indonesia
}

\begin{abstract}
This study aims to find out: 1) Differences in the character of students taught with a local wisdom-based learning approach compared with conventional approaches, 2) Differences in the character of students who understand high diversity values compared to students who understand low diversity values, and 3) Interactions between learning approaches and the value of diversity towards the character development of elementary school students. This research was conducted at State Elementary School 057211 Emp. Cinta Raja, Secanggang District, Langkat Regency. The population in this study was grade IV students, amounting to 32 people. The sample in this study was class IV/an as an experimental class consisting of 16 students and class IV/b as a control class consisting of 16 students. The data collection technique is done by observing the diversity values and observing the development of student character. Data analysis techniques used the Two Way Anova test with a $2 \times 2$ factorial design. The results showed that: (1) There was a significant difference between the character of students being taught with a local wisdom-based learning approach compared to the conventional approach $\left(F_{\text {coum }}=28,167\right.$ and sig. $\left.0,000<0,05\right)$; (2) There is a significant difference between the characters of students who understand high diversity values compared to low comprehension $\left(\mathrm{F}_{\text {count }}=65,425\right.$ and sig. $\left.0,000<0,05\right)$; (3) There is an interaction between the learning approach based on local wisdom and diversity values towards the development of student character $\left(F_{\text {count }}=9,884\right.$ and sig. $\left.0,004<0,05\right)$.
\end{abstract}

Keywords: Learning approach, local wisdom, diversity values, character

\section{Introduction}

Learning can be interpreted as a very important part of the core of education. The actual implementation of learning in the field tends to be conventional, the learning that occurs is still dominated by the activeness of the teacher. There are not many teachers who can creatively or innovatively create interesting learning for students even though the government has been trying to improve teacher competence. If this continues it will have an impact on student learning outcomes so that it will result in a decrease in the quality of education in a country. Civilization will decline if there is a demoralization in the community besides that the quality of education is also a determining factor in the progress of civilization in an area. 
Indonesia has different ethnic and cultural riches, each tribe has different cultural values and characteristics from each region from Sabang to Merauke. Medan is a multi-ethnic city whose population consists of people from different cultural and religious backgrounds. Ethnic Malays are the first ethnic groups in Medan, and after that, several tribes came to Medan, namely Javanese, Batak, Chinese, Mandailing, and Indians [1]. As a city that has diverse ethnicities and cultures, of course, this becomes the main job for teachers to preserve local culture so that the local cultural values of the region do not fade in the eyes of students. The Malay Community is one of eight ethnic cultures of the indigenous people in North Sumatra Province. This is supported by the legacy of the Melayu Deli kingdom history, namely: Maimun Palace and Masjid Raya Medan Matsum City so that Melayu Deli is used as a cultural identity in the city of Medan.

In addition to local cultural values, diversity values also need to be instilled in students from an early age. Because the value of diversity is a value that can be used as a guide to determine good or bad behavior in people's lives. There are several diversity values that must be instilled in students from an early age including 1) The value of tolerance is an attitude to recognize and respect human rights in social life; 2) the value of equality is an attitude that emphasizes equality and equality with other ethnic cultures; 3 ) the value of democracy is an attitude that recognizes that everyone has the same rights and obligations and recognizes diversity as a natural thing, and 4) justice is an act that gives equal rights to people who have the same status [2].

The current of globalization can threaten the existence of Indonesian culture, for example, the loss of a culture of silaturrahmi (friendships), a decline in a sense of nationalism and the fading nature of family and self-confidence as a nation. Therefore this study aims to look at the effect of North Sumatra's local culture-based learning and diversity values on student learning outcomes in the city of Medan. From the values of cultural wisdom and diversity values, it is expected to form students' character values. Character is an effort in the realization of the mandate of the Pancasila and the Preamble to the 1945 Constitution which is motivated by the reality of the national problems that are developing at this time, such as disorientation and not living the values of Pancasila [3]. Every nation everywhere must always have attitude guidelines that are used as a reference in society. Likewise with the Indonesian people, for the Indonesian people, the attitude of life that is believed to be true is Pancasila, and people whose life attitude is believed to be with Pancasila, they will maintain and even hold a proud culture of pride. Character education is a system of inculcating character values to school members that includes components of knowledge, awareness or will, and actions to carry out these values, both towards God Almighty, oneself, others, the environment, and nationality so that we become human beings. In character education in schools, all components (stakeholders) must be involved, including the components of education itself, namely the contents of the curriculum, the learning and assessment process, the quality of relationships, the handling or management of subjects, school management, implementation of activities, empowerment of infrastructure, funding, and the work ethic of all citizens and the school environment.

Based on the above statement it can be concluded that local cultural wisdom must be interpreted and must be maintained. People who preserve local culture means that they already have the values of diversity that are in possession so that the existence of diversity values is expected to form good character within. 


\section{Research methods}

The method used in this research is a quasi-experiment with a $2 \times 2$ factorial design. This research was conducted at State Elementary School 057211 Emp. Cinta Raja Secanggang Subdistrict, Langkat Regency, North Sumatra. The population in this study was grade IV students, amounting to 32 people. The sample in this study was class IV/an as an experimental class consisting of 16 students and class IV/b as a control class consisting of 16 students. Data collection techniques in this study used the diversity value questionnaire and the character development questionnaire for students. Furthermore, data analysis techniques in this study use inferential statistical techniques. Hypothesis testing is calculated using the Two Way Anova test with a significant level of 0,05 . Besides, the data analysis requirements test is the normality test calculated using the Shapiro-Wilk test, while the homogeneity test data is calculated using the Levene test at a significant level of 0,05 .

\section{Results and discussion}

\subsection{Data description}

Before conducting the treatment, the student's character values are pre-tested. The following is the frequency distribution of the pretest results from the two sample classes.

Table 1. Distribution of Pre-Test Results for Student Character Values

\begin{tabular}{cccccc}
\hline & Experimental Class & \multicolumn{3}{c}{ Control Class } \\
\hline Interval & Frequency & $\%$ & Interval & Frequency & $\%$ \\
$50-56$ & 3 & $19 \%$ & $45-53$ & 3 & $19 \%$ \\
$57-63$ & 5 & $31 \%$ & $54-62$ & 7 & $44 \%$ \\
$64-70$ & 7 & $44 \%$ & $63-71$ & 5 & $31 \%$ \\
$71-77$ & 1 & $6 \%$ & $72-80$ & 1 & $6 \%$ \\
Amount & 16 & $100 \%$ & Amount & 16 & $100 \%$ \\
\hline
\end{tabular}

Based on Table 1 it can be concluded that the average character value between the two sample classes is relatively the same or homogeneous. The frequency distribution table data can be described in the form of a histogram as follows: 


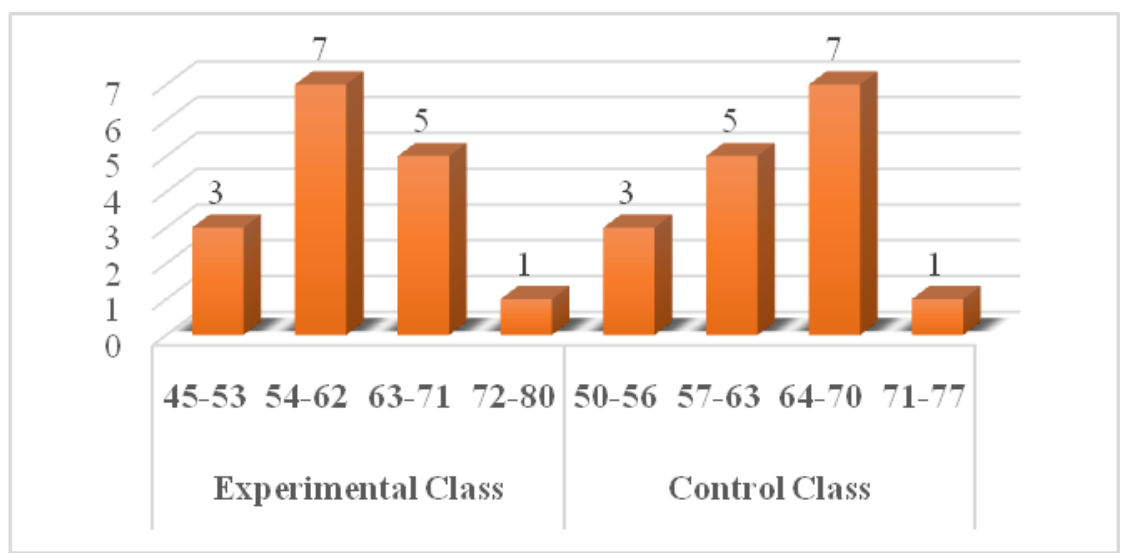

Fig. 1. Histogram Pre-Test Student Character Value for Experiment and Control Classes

From the results of statistical calculations it is known that the character values of students taught with a local wisdom-based learning approach get the lowest score of 80 , and the highest score of 95 , with an average of 87.50; variance of 26.67 and standard deviation of 5.16. The frequency distribution of the character values of students taught by the local wisdom-based learning approach is presented in the following Table.

Table 2. Frequency Distribution of Student Character Values Taught by the Learning Approach based on Local Wisdom

\begin{tabular}{ccc}
\hline Interval & Frequency & Percentage $(\%)$ \\
\hline $80-83$ & 3 & $19 \%$ \\
$84-87$ & 5 & $31 \%$ \\
$88-91$ & 5 & $31 \%$ \\
$92-95$ & 3 & $19 \%$ \\
Amount & 16 & $100 \%$ \\
\hline
\end{tabular}

Visually the frequency distribution of student character values taught by the local wisdom-based learning approach is shown in the following histogram: 


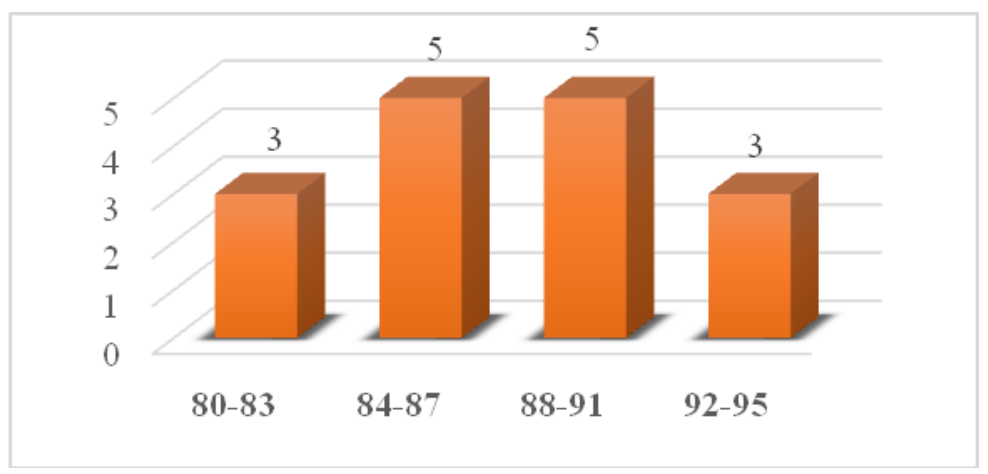

Fig. 2. Histogram Student Character Values Taught by Learning Approaches Based on Local Wisdom

From the results of statistical calculations it is known that the character values of students taught with conventional approaches get the lowest score of 55, and the highest score of 95, with an average of 78.13; variance of 126.25 and standard deviation of 11.24. The frequency distribution of student character values taught by conventional learning approaches is presented in the following Table.

Table 3. Frequency Distribution of Student Character Values Taught by Conventional Approaches

\begin{tabular}{ccc}
\hline Interval & Frequency & Percentage $(\%)$ \\
\hline $55-65$ & 3 & $19 \%$ \\
$66-76$ & 4 & $25 \%$ \\
$77-87$ & 6 & $38 \%$ \\
$88-98$ & 3 & $19 \%$ \\
Amount & 16 & $100 \%$ \\
\hline
\end{tabular}

Visually the frequency distribution of student character values taught by conventional approaches is shown in the following histogram:

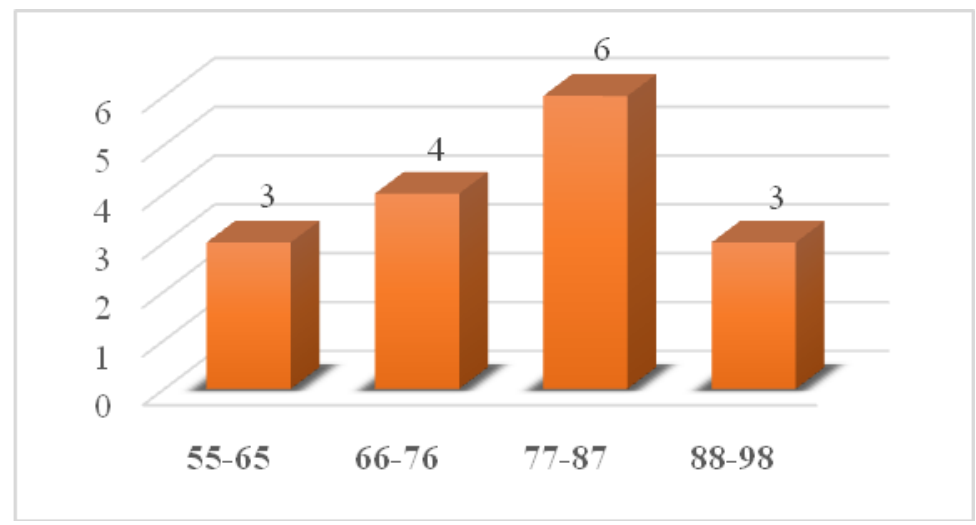

Fig. 3. Histograms of Student Character Values Taught by Conventional Approaches 


\subsection{Prerequisite test}

\subsubsection{Normality test}

\begin{tabular}{lccccccc}
\hline \multicolumn{1}{c}{ Tests of Normality } \\
& \multicolumn{3}{c}{ Kolmogorov-Smirnov $^{\mathrm{a}}$} & \multicolumn{4}{c}{ Shapiro-Wilk } \\
& Statistics & df & Sig. & Statistics & df & Sig. \\
$\begin{array}{l}\text { Standardized Residual for } \\
\text { Student_Characters }\end{array}$ &, 138 & 32 &, 125 &, 935 & 32 &, 054 \\
\hline
\end{tabular}

a. Lilliefors Significance Correction

Based on the table above shows that the results of normality testing of research data obtain a probability value or significant value of $0,054>0,05$ thus it can be concluded that the research data is normally distributed.

\subsubsection{Homogeneity test}

\begin{tabular}{l}
\hline \multicolumn{3}{c}{ Levene's Test of Equality of Error Variances } \\
$\begin{array}{l}\text { Dependent Variable: Character Value } \\
\text { F }\end{array}$ df1 \\
1,843
\end{tabular}

Based on the table above shows that the homogeneity of research data obtained the probability value or sig value. of $0,162>0,05$ thus it can be concluded that the research data groups are relatively the same or homogeneous.

\subsection{Hypothesis testing}

Testing the research hypothesis using the two-way ANOVA test with a 2x2 factorial design. Hypothesis testing data can be seen in the following table:

Table 4. SPSS Two Way ANOVA Calculation Results

\begin{tabular}{lrrrrr}
\hline Type III Sum of & & & & \\
Source & Squares & df & Mean Square & \multicolumn{1}{c}{ F } & \multicolumn{1}{c}{ Sig. } \\
\hline Corrected Model & $2377,629^{\mathrm{a}}$ & 3 & 792,543 & 35,836 &, 000 \\
Intercept & 216370,961 & 1 & 216370,961 & 9783,489 &, 000 \\
Learning_approaches & 622,929 & 1 & 622,929 & 28,167 &, 000 \\
Value_Diversity & 1446,945 & 1 & 1446,945 & 65,425 &, 000 \\
Learning_approachesPe & & & & & \\
mbelajaran * & 218,598 & 1 & 218,598 & 9,884 &, 004 \\
Value_Diversity & & & & & \\
Error & 619,246 & 28 & 22,116 & & \\
Total & 222450,000 & 32 & & & \\
Corrected Total & 2996,875 & 31 & & & \\
\hline a. R Squared $=, 793$ (Adjusted R Squared $=, 771)$ & & &
\end{tabular}

a. R Squared $=, 793$ (Adjusted R Squared $=, 771$ ) 


\section{Hypothesis I \\ Ho : $\mu \mathrm{A}_{1}=\mu \mathrm{A}_{2}$ \\ Ha: $\mu \mathrm{A}_{1} \neq \mu \mathrm{A}_{2}$}

Based on the SPSS output in Table 4 it was found that the Fcount value in the learning approach was 28,167 and the significant value was $0,000<0,05$. Thus testing the hypothesis rejects $\mathrm{Ho}$ and accepts $\mathrm{Ha}$. So it can be concluded that there is a significant difference between the character of students being taught with a local wisdom-based learning approach compared to the conventional approach

\section{Hipotesis II}

Ho : $\mu \mathrm{B}_{1}=\mu \mathrm{B}_{2}$

$\mathrm{Ha}: \mu \mathrm{B}_{1} \neq \mu \mathrm{B}_{2}$

Based on the SPSS output in Table 4 it was found that the Fcount value on the Diversity Value is 65,425 and the significant value is $0,000<0,05$. Thus testing the hypothesis rejects Ho and accepts Ha. So it can be concluded that there are significant differences between the characters of students who have an understanding of high diversity values compared with students who have an understanding of low diversity values.

\section{Hipotesis III}

$$
\begin{aligned}
& \text { Ho: } \mathrm{A} \times \mathrm{B}=0 \\
& \text { Ha: } \mathrm{A} \times \mathrm{B} \neq 0
\end{aligned}
$$

Based on the SPSS output in Table 4 it is obtained that Fcount $=9,884$ and significant value of $0,004<0,05$ so that the hypothesis testing rejects Ho and accepts Ha. Thus it can be concluded that there is an interaction between learning approaches and understanding the value of diversity in influencing the development of student character. The results of these interactions can be seen in the following figure.

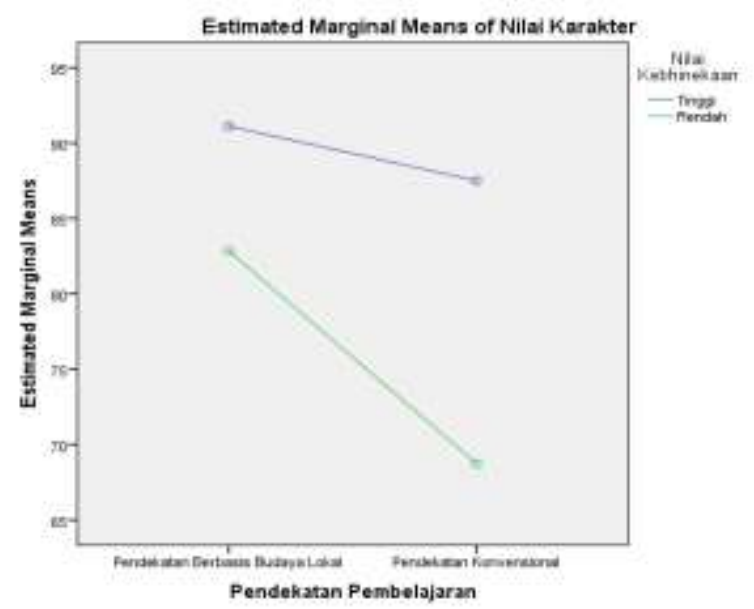

Fig. 4. Interaction of Learning Approaches and Understanding Diversity Values on Student Character Development 
The influence of globalization has given birth to new values, new lifestyles and new patterns of social interaction with all its consequences including sharp social inequality, broken character among people with many conflicts between ethnic groups, changes in family values and functions, individualism and a sense of indifference to others, thin feeling of solidarity and togetherness, loss of love for domestic products, depletion of love and respect for local cultural values. Local wisdom found in several indigenous groups/communities in Indonesia contains a great deal of the nation's cultural values which are still strong into the character identities of its citizens. But on the other hand, the value of local wisdom is often ignored, because it is considered not following the times [4]. Therefore it is necessary to create a change in learning patterns, especially in elementary schools, because not infrequently the good and bad character of a person starts from the elementary school. Besides, the progress of globalization will expose students to the many choices about good grades that are good grades to emulate and vice versa [5]. Values that are considered good by a community group are not something that will not fade and be replaced by new values that are not necessarily under the culture of the surrounding community. Besides, that local wisdom can function as one of the noble values.

\section{Conclusion}

Based on the results of research and discussion that has been described previously, then some conclusions can be drawn including the following: there is a significant difference between the character of students being taught with a local wisdom-based learning approach compared to the conventional approach $\left(\mathrm{F}_{\text {count }}=28,167\right.$ and a value of sig. $\left.0,000<0,05\right)$; there is a significant difference between the characters of students who understand high diversity values compared to low comprehension $\left(\mathrm{F}_{\text {count }}=65,425\right.$ and sig. $\left.0,000<0.05\right)$; and there is an interaction between the learning approach based on local wisdom and diversity values on the development of student character $\left(F_{\text {count }}=9,884\right.$ and sig. $\left.0,004<0,05\right)$.

\section{References}

[1] https://id.wikipedia.org/wiki/Kota_Medan

[2] W. Amuk. Pembelajaran Nilai-nilai Multikulturalisme dalam Teks Sastra. https://dyanarsya.wordpress.com.

[3] Fatmawati and F. Yani. Nilai-nilai dalam Pendidikan Karakter Bangsa yang Berdasarkan Pancasila dan UUD 1945,“ rev. Prosiding Seminar Nasional Tahunan Fakultas Ilmu Sosial Universitas Negeri Medan, Medan, 2017.

[4] M. Priyatna. Pendidikan Karakter Berbasis Kearifan Lokal. Jurnal Pendidikan Islam, zV. 5 (10), 2016.

[5] Yusrizal. Pendidikan Karakter Berbasis Kearifan Lokal pada Pelajaran IPS untuk Siswa Sekolah Dasar.Prosiding Seminar Nasional Tahunan Fakultas Ilmu Sosial Universitas Negeri Medan, Medan, 2017. 